\title{
3-D Modelling of Basic Weft-Knitted Fabric Structures
}

\author{
FUKUTA Yuka $^{\mathrm{a}, \mathrm{b}, *}$, Ohta Kouichi ${ }^{\mathrm{a}}$, KINARI Toshiyasu ${ }^{\mathrm{b}}$ \\ a Owari Textile Research Center, AITEC, Aichi Prefectural Government, 35 Miyaura, Mabiki, Yamato-cho, Ichinoiya, \\ Aichi 491-0931, Japan \\ ${ }^{\mathrm{b}}$ Graduate School of Natural Science and Technology, Kanazawa University, Kakuma-machi, Kanazawa 920-1192, Japan
}

Received 11 December 2009; accepted for publication 9 December 2010

\begin{abstract}
Based on the structural analysis of sample knitted fabrics and the knit geometric theory, we have built an algorithm that can make three-dimensional structure models for weft knitted fabrics such as welt stitches, tuck stitches, cross stitches, rib stitches and purl stitches. In order to reduce computational complexity, we have set the anchoring point on the diametral plane of yarn in the knitting chart. Drawing from the beginning knitting point to the finished knitting point, a smooth knit curve model can be obtained with the cardinal spline curve. Using this algorithm, we have developed the weft knit three-dimensional structure modeling software that can display the threedimensional model of knitted fabrics including welt stitches; tuck stitches, cross stitches, rib stitches and purl stitches.

Our work confirms 3-D modeling of three foundation knits of weft knit (plain stitches, purl stitches, rib stitches), tuck stitches, welt stitches and cross stitches with a commercially available PC. This software can be used by someone with no understanding of knitting to gain an understanding of the knitting process, and determine the structure of a knitted fabric product.
\end{abstract}

Key Words: Knit, 3-D modeling, Tuck, Welt, Rib, Purl

\author{
よこ編基本組織の 3 次元モデリング手法 \\ 福田ゆか ${ }^{\mathrm{a}, \mathrm{b}, *}$ ，太田幸一 ${ }^{\mathrm{a}}$, 喜成年泰 ${ }^{\mathrm{b}}$ \\ ${ }^{a}$ 愛知県産業技術研究所尾張瀻維技術センター, ${ }^{b}$ 金沢大学大学院自然科学研究科
}

\section{1.まえがき}

よこ編に代表されるニットはその伸縮性から，近年衣料用 だけでなくさまざまな用途に用いられつつある。近年種々の 製造業において, 金属, プラスチック部品等はCAEによる 設計が広範囲で導入され，製品開発の効率化に寄与してい る。しかし, 繊維素材のような柔素材では CAE 技術が確立 されていないため, 製品開発におけるボトルネックとなって いる. 特に, ニットは織物に比べ 3 次元モデリングの研究開 発が進んで扔らず，これを実現することにより，ニットの生 産現場では, サンプル作成の手間を省き, 製品開発の効率化 を図ることが可能になる。
編目の幾何学形状の研究は古くから行われており, Peirce [1] はループ長を糸の直径の 16.663 倍に限定し, ループ長 と糸の直径, ループ密度との関係を解析している. その後 Leaf ら［2］は，より安定したループ構造になるための新し いモデルを提案した。ループは歪エネルギーを最小にする形 状となるよう詳細なループ形状を, サインカーブを用いた方 程式で表した。一方ループ長, 密度, 糸の直径, 編地の長 さ・幅・厚さの関係について実験的な研究が盛んに進められ た [3].

近年コンピュータの性能が向上したことにより, 複雑な方 程式で与えられる形状を容易に描画できるようになった。 Kurbak らは編地の糸の曲げ歪みエネルギーから編地のカー リング $[4]$, 糸の解撚トルクエネルギーから斜行のシミュ

\footnotetext{
* 連絡先：愛知県産業技術研究所尾張繊維技術センター 491-0931 一宮市大和町馬引宮浦 35, E-mail: yuka_fukuda@pref.aichi.lg.jp, Tel: +81-586-45-7871, Fax: +81-586-45-0509
} 
レーションを行っている [5]，またカーリングのモデルを局 所的なカーブとして応用し, $\mathrm{n} \times \mathrm{m}$ のリブ編みモデルに用い ている. Kurbakらはさらに糸の曲げ歪みエネルギーを考慮 してパール編み組織 [6], ミス（ウェルト）組織 [7]，タッ ク組織 [8] の各種組織のモデル化を行っている。西条らは, 平編地の 3 次元形状モデリングに加え, 糸の解撚トルクによ り起こる斜行のシミュレーションを行っている [9].これら の研究では, 編目の詳細な 3 次元形状やカーリング, 斜行と いった糸の歪みエネルギーから, 編地形状の変形を予測して いる。しかし，モデルを算出表示するためには，膨大な計算 量を必要とし，時間がかかる。また編組織図等の設計のデー 夕に基づいていないため, 製品開発の効率化のための 3 次元 モデル作成とはなっていない.

鈴木ら [10］の出願特許では, 編地の各編目に対してその 上下左右の編目との相対位置に基づいて編目を移動させ, 影 を付けることで 3 次元的に表現し, よりリアルな編地のシ ミュレーションを製品設計の作業で使用できるよう行ってい る。精細なループシミュレーションが短時間でできるとして いる. 森本ら [11］の出願特許では，ニット製品のパターン から編目の 2 次元のシミュレーション画像を作成し, パター ンの 3 次元シミュレーション画像に編目画像をマッピングす ることにより，よりリアルなニット製品の 3 次元モデル化を 行っている.これらの研究では, 編組織図などから 2 次元の 編地のシミュレーションをしたのちに 3 次元の製品に編目画 像をマッピングすることで製品のリアルなシミュレーション が可能となっているが, 編目そのものの 3 次元形状シミュ レーションは行われていない.

古川ら［12］の出願特許では, 編組織図を基に糸の連結点 を 3 次元の格子状に配列し, タック, ウェルト組織部分では 格子を変化させ，その格子を接続することで編組織図に対応 した編地の 3 次元シミュレーション画像を生成している.

我々の研究の目的は，ニット製品の企画設計のデー夕を基 にしたニット製品の 3 次元モデリングと表示のためのソフト ウェアの開発である。一般的に, 3 次元モデルは 2 次元画像 データと比較し, CAD 等での処理が可能で, ソフトウェア 間の互換性が高いという利点がある。ささらに, 編地を 3 次元 モデルにより表現できれば，ニット製品のできあがり形状と サイズの予測などが可能となるため, ニット製品開発の効率 化が期待できる.

ニット製品の 3 次元モデリングを行うにあたり，まず，横 編機, 丸編機で編成できる基本的なよこ編組織の 3 次元モデ リング手法についての検討を行うこととし, 編地の形状を作 る減らし目, 増やし目についての検討は, 後の研究課題とす る.

また，汎用的なパソコンで使用可能なソフトウェアにする ため, 計算量を減じるアルゴリズムについて検討する。

本報告では, サンプルニット生地の構造解析を行い, サン プルニット生地の実測值とニット幾何学の理論をもとに, 平 編, タック, ウェルト, 移し目, ゴム編, パール編の組織に ついて 3 次元モデリングを行い, それらの組織で構成される 編地を表示するソフトウェアを開発したので, その結果につ
いて報告する

\section{2. ソフトウェアの開発環境}

ソフトウェア開発環境としては, OS：Windows XP, プロ グラム言語はVisual Basic2005を用いた. 3 次元画像表示の API にはDirectX9 を用いた。 DirectX9を用いた利点として は, Visual Basic2005 での 3 次元画像表示が可能なため開発 言語を 1 本化できること, CPU の負担が減るため表示処理 の高速化が期待できることがある.

\section{3.よこ編組織の 3 次元モデリングソフト ウェアの開発}

平編（天竺）組織の一つのループを基本ループとすると, 基本ループは古くから幾何学構造の解析と実際の編地の検証 がなされており, Peirce, Leaf等の幾何学理論の数式を用い れば, 基本ループの 3 次元モデリングができる。しかし, タック, ウェルト組織等 (変化組織) はループが交錯する構 造が基本ループと異なるので，ループの形状を変形させる必 要があり幾何学理論の数式そのままではモデリングすること ができない，基本ループの曲線をスムーズに表現するために は多量の頂点座標が必要になるが, 基本ループ以外の組織を 表現する時その一つ一つの移動を計算するには時間がかかる ため, 最小限の組織図を基にし, 組織の位置となる基準点 （以下組織基準点とする）と系の通る中心点となる基準点 (以 下糸中心基準点）を算出してから, カーディナルスプライン 曲線の数式を用いスムーズな曲線を描くように中間座標を求 めることとした。

組織図（Fig. 1）または編方図の入力, ウェール密度, コー 久密度, 番手の設定を基として, 編地の 3 次元モデリングを

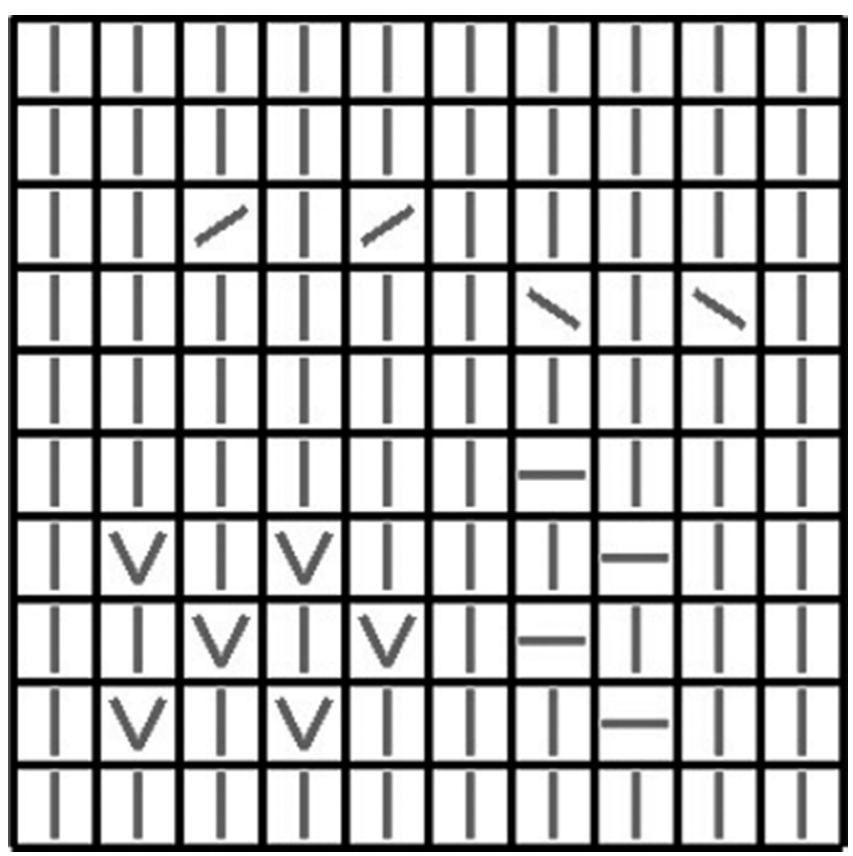

Fig. 1 Knitting chart. 
行うソフトウェアの開発を行った。組織図と編目密度を設定 し, 組織基準点および編地の編み始めのループから編み終わ りのループまで順番に糸中心基準点を算出した。編み始めか ら編み終わりまでの糸中心基準点を通るカーディナルスプラ イン曲線として編地の 3 次元モデルを描くため, 2 点の糸中 心基準点の間に 4 点または 9 点の糸中心座標を数式により補 間した。

カーディナルスプライン曲線は以下の式より求めた。

$\mathrm{X}$ 座標について

$$
\begin{aligned}
& 【 \mathrm{~A}_{\mathrm{x}}=\mathrm{T}\left(\mathrm{X}_{2}-\mathrm{X}_{0}\right)+\mathrm{T}\left(\mathrm{X}_{3}-\mathrm{X}_{1}\right)+2 \mathrm{X}_{1}-2 \mathrm{X}_{2}, \\
& \mathrm{~B}_{\mathrm{x}}=-2 \mathrm{~T}\left(\mathrm{X}_{2}-\mathrm{X}_{0}\right)-\mathrm{T}\left(\mathrm{X}_{3}-\mathrm{X}_{1}\right)-3 \mathrm{X}_{1}+3 \mathrm{X}_{2}, \\
& \mathrm{C}_{\mathrm{x}}=\mathrm{T}\left(\mathrm{X}_{2}-\mathrm{X}_{0}\right), \quad \mathrm{D}_{\mathrm{x}}=\mathrm{X}_{1}, \mathrm{~T}=0.7, \\
& \mathrm{X}^{\prime}(\mathrm{n})=\mathrm{A}_{\mathrm{x}} \mathrm{t}^{3}+\mathrm{B}_{\mathrm{x}} \mathrm{t}^{2}+\mathrm{C}_{\mathrm{x}} \mathrm{t}+\mathrm{D}, \mathrm{t}=\mathrm{n} / \mathrm{m} 】
\end{aligned}
$$

$\mathrm{X}_{0}, \mathrm{X}_{1}, \mathrm{X}_{2}, \mathrm{X}_{3}$ : 系中心基準点の座標, $\mathrm{n}$ : 補間する座標 の $\mathrm{n}$ 番目 $, \mathrm{m}: 2$ 点間を補間する座標の総数

座標 $\mathrm{X}_{0}, \mathrm{X}_{1}, \mathrm{X}_{2}, \mathrm{X}_{3}$ から $\mathrm{X}_{1}, \mathrm{X}_{2}$ 間の補間座標を算出。 $\mathrm{T}$ は線分の硬さに対応する変数. ループ長が糸の直径の 16.7 倍になる数値として $\mathrm{T}=0.7$ と設定.

$\mathrm{Y}$ 座標, $\mathrm{Z}$ 座標についても同様の式で求めた

ここで糸直径は, 入力番手から織物の理論密度 Ashenhurst の計算式に用いられる直径数の式（1 inch 間に重ならずに密 接して並べられる糸本数) より求めた.

$$
\mathrm{d}=2.54 /(\mathrm{K} \sqrt{840 \times \mathrm{N} \times 0.591})
$$

$\mathrm{d}$ : 糸直径 $\mathrm{N}$ ：共通式番手 $\mathrm{K}$ ：原料によって決ま る定数（綿：0.93, 梳毛 : 0.90)

糸の断面は, 対角線が糸の直径となる正八角形とし, 糸中 心がカーディナルスプライン曲線を描く正八角形の筒のつな がりとして頂点座標を求め, DirectX9により 3 次元画像とし て表示した。

設定を糸の番手のみとした場合, 糸の番手から求めた直径 に対し適正な編目密度を求め 3 次元モデルの頂点座標を算出 した。編目密度に対し理論值よりも細い番手で編地の編成は 可能である。 そこで編目密度と番手を両方設定したとき, 糸 中心基準点を算出するための糸の直径は編目密度から算出 し, 糸の断面である正八角形の頂点は設定した番手から算出 した。

\section{4. 基本ループのモデリング}

基本ループの組織基準点と糸中心基準点を以下に示すよう に求めた，共通式番手に換算して 2 番手の綿麻の手芸糸で平 編サンプルを作成し, 編地サイズ（ウェール密度 : 2 目/ cm, コース密度 : 2.3 目 $/ \mathrm{cm}$, 編地の厚さ : $2.3 \mathrm{~mm}$, 密度より求 めた糸直径 $\mathrm{d} ： 1.25 \mathrm{~mm}$ ）を実測し，基本ループのモデルと 比較した.

\section{1 組織基準点の設定}

各組織点に入力された組織情報（組織図）を基に編目のモ デルを作成するため，1 ループの編目のモデル化に上下 2 点 の組織の位置となる基準点（以下組織基準点とする）を定め
ることとした (Fig. 2). Fig. 2 に示すように組織基準点 2 点 を, ウェール密度から求められるループの幅の中心線とコー ス密度から求められるコース幅の上下の線の交錯点 2 点に定 めることとした。組織図, ウェール密度, コース密度より, 編地全体のサイズと各ループの組織基準点を設定する（Fig. 3）。上下左右の組織の関係からこの 2 点の組織基準点を移動 することにより移し目，ゴム編など，左右の伸縮をコント ロールする．

\section{2 糸中心基準点の設定}

各編目構造をモデル化するため, 基本ループの 1 ループの 編目において糸の通る中心点となる 6 点の基準点（以下糸中 心基準点）を定めて行うこととした（Fig. 2). Fig. 2 の 7 点 目の糸中心基準点は次のループの 1 点目となるため, 算出す る基準点は 6 点となる

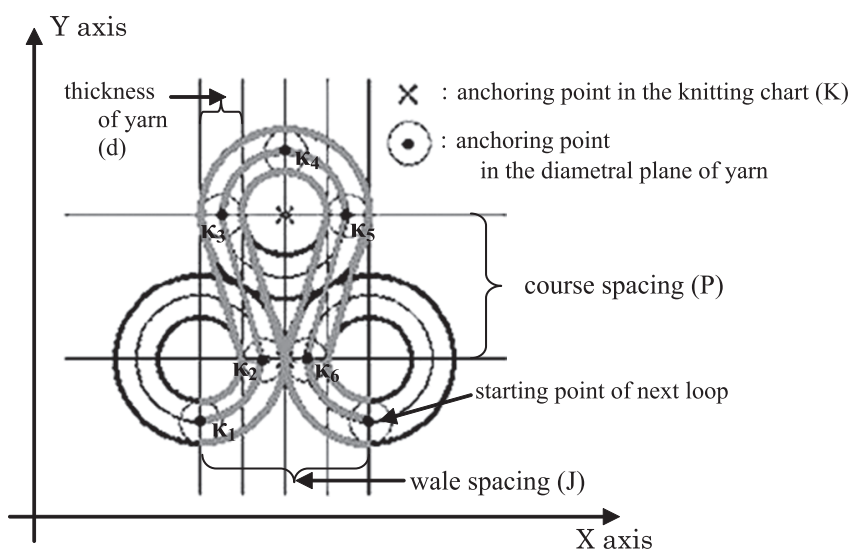

Fig. 2 Anchoring point in the XY plane (The plane view of knitted fabric).

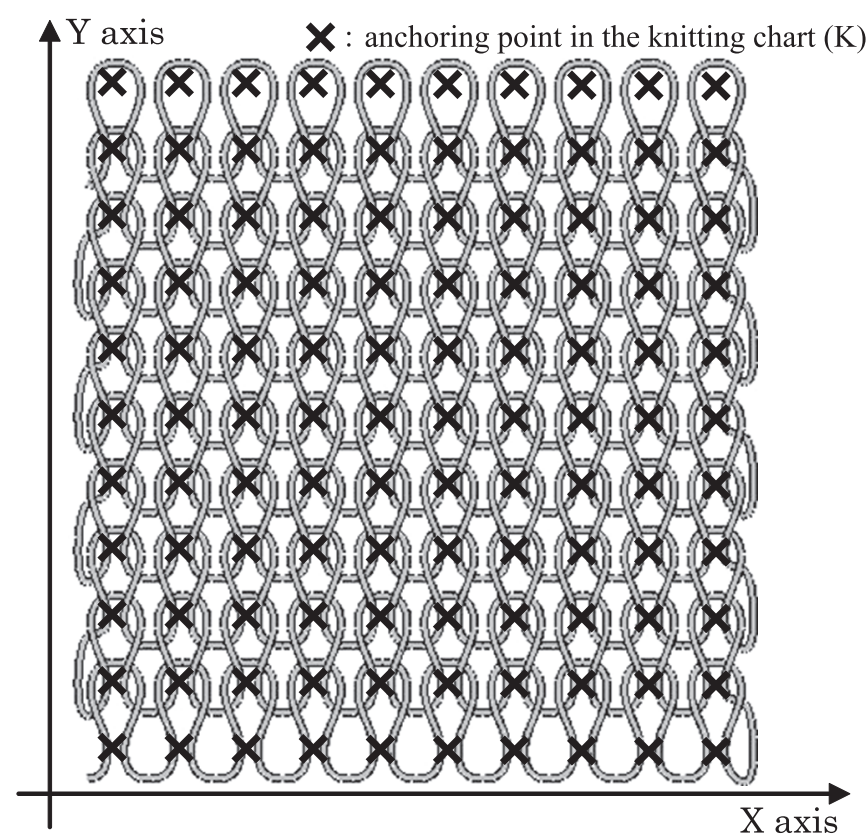

Fig. 3 Anchoring point in the XY plane (The plane view of knitted fabric). 
編目の幾何学構造を最初にモデル化した Peirceの簡略図 （Fig. 2）を $\mathrm{xy}$ 平面，編地の厚さを $\mathrm{yz}$ 平面（Fig. 4）で示す. 基本ループでは糸が交錯する 4 点において糸が拘束され方向 が変わるため, まずこの 4 点を糸中心基準点とする，糸の交 錯する 4 点の間で, 糸は平編地の表側に盛り上がる。ループ の上下頂点 2 点は平編地の裏側に沈む. 糸の交錯する 4 点と ループの上下頂点 2 点の $\mathrm{Z}$ 軸方向での差により編地の厚さ を計算できる，よって基本ループでは，糸の交錯する点と上 下頂点 2 点の 6 点を糸中心基準点とした。

基本ループを 6 点の糸中心基準点を通る曲線として表すた め, 平編の編目構造から 6 点の糸中心基準点の位置を検討し た。

ウェール密度とコース密度から算出した組織基準点から, 1 ループの編目がその中に扮さまるようにループの高さと幅 を計算しモデル化する。糸中心基準点は組織基準点を基にし て算出し, 編目をモデル化する。基本ループでは, ウェール 密度（単位：目/cm）はループの幅に相当するが, 頂点 2 点 は上下の編目と重なるため, 4 点の糸交錯点がコース密度 （単位：目 $/ \mathrm{cm}$ ) に相当する。

Fig. 2 に示す基本的な幾何学モデルでは，平編地ですきま なくループが配列されたと仮定すると, ウェール密度 W, コース密度 $\mathrm{C}$, ループ長 $\ell$, 糸の直径 $\mathrm{d}$, 下の交錯点と上の 交錯点の間隔 $\mathrm{P}$, ループの幅 $\mathrm{J}$ は以下の関係である.

$$
\begin{aligned}
& \mathrm{P}=1 / \mathrm{C} \\
& \mathrm{J}=1 / \mathrm{W} \\
& \mathrm{P}=3.46 \mathrm{~d} \\
& \mathrm{~J}=4 \mathrm{~d} \\
& \ell=16.7 \mathrm{~d}
\end{aligned}
$$

例えば編機で右行きで編まれるループでは糸は左から右へ 通るため, 糸中心基準点を左下から順番（左行きの場合は右 下から順番）に $\kappa_{1}, \kappa_{2}, \kappa_{3}, \kappa_{4}, \kappa_{5}, \kappa_{6}$ とする。組織基準点を $\mathrm{K}$ （上の組織基準点を $\mathrm{K}_{\mathrm{u}}$, 下の組織基準点を $\mathrm{K}_{\mathrm{d}}$ ）とする. 上の組織基準点は 1 コース上のループの下の組織基準点とな

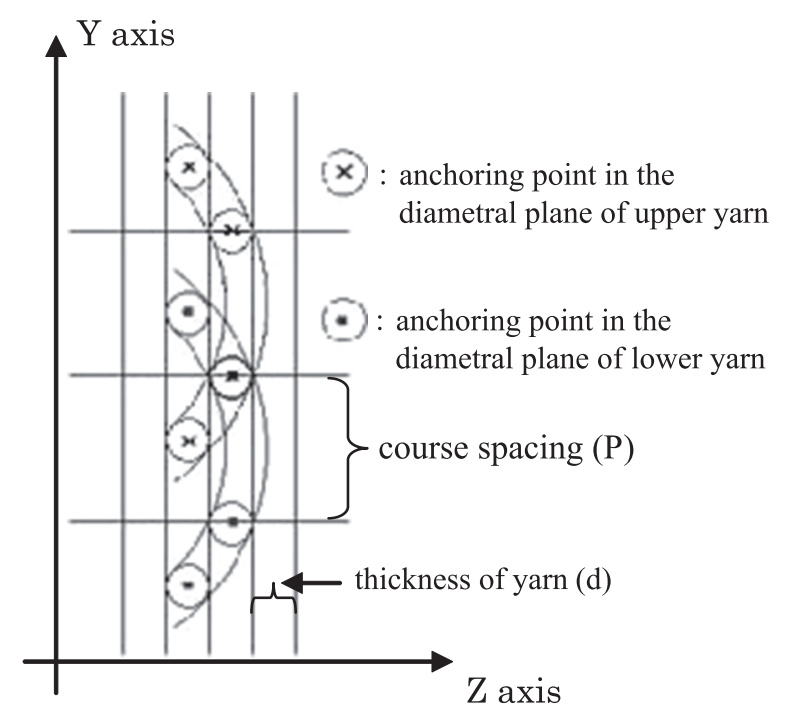

Fig. 4 Anchoring point in the YZ plane (The cross section of knitted fabric).
る。糸の直径 $\mathrm{d}$ は 1 ループの幅の $1 / 4$ であるため, 糸が交錯 する上の 2 点で糸の中心は糸の半径分ウェール密度で求めら れる 1 ループの幅の端から内側に入り，下の 2 点はウェール 密度で求められる 1 ループの中心より糸の半径分外側とな る.よって糸が交錯する上の系中心基準点 2 点 $\left(\kappa_{3}, \kappa_{5}\right)$ の $\mathrm{X}$ 座標 $\left(\kappa_{3 \mathrm{x}}, \kappa_{5 \mathrm{x}}\right)$ は,

$$
\kappa_{3 \mathrm{x}}=\mathrm{K}_{\mathrm{ux}}-(\mathrm{J} \times 3 / 8), \quad \kappa_{5 \mathrm{x}}=\mathrm{K}_{\mathrm{ux}}+(\mathrm{J} \times 3 / 8)
$$

とした。 $\mathrm{Y}$ 座標 $\left(\kappa_{3 y}, \kappa_{5 \mathrm{y}}\right)$ については, 糸中心基準点の $\mathrm{Y}$ 座標 $=$ 組織基準点の $\mathrm{Y}$ 座標である.

下の糸中心基準点 2 点 $\left(\kappa_{2}, \kappa_{6}\right)$ の $\mathrm{X}$ 座標 $\left(\kappa_{2 \mathrm{x}}, \kappa_{6 \mathrm{x}}\right)$ は,

$$
\kappa_{2 \mathrm{x}}=\mathrm{K}_{\mathrm{dx}}-(\mathrm{J} \times 1 / 8), \quad \kappa_{6 \mathrm{x}}=\mathrm{K}_{\mathrm{dx}}+(\mathrm{J} \times 1 / 8)
$$

とした. $\mathrm{Y}$ 座標 $\left(\kappa_{2 \mathrm{y}}, \kappa_{6 \mathrm{y}}\right)$ については, 糸中心基準点の $\mathrm{Y}$ 座標 $=$ 組織基準点の $\mathrm{Y}$ 座標である.

サンプルの実測值およびループの頂点が接することから， ループの高さはコース密度から求められるコースの間隔の 2 倍になる。よって上下頂点はコース密度の $1 / 2$ 重なってい る。また糸の半径分だけ内側に入るため, 上の頂点の糸中心 基準点 $\left(\kappa_{4}\right)$ の $\mathrm{Y}$ 座標 $\left(\kappa_{4 \mathrm{y}}\right)$ は,

$$
\kappa_{4 \mathrm{y}}=\mathrm{K}_{\mathrm{u}}+\mathrm{P} \times 1 / 2-\mathrm{d} / 2
$$

とし, 下の頂点の糸中心基準点 $\left(\kappa_{1}\right)$ のY座標 $\left(\kappa_{1 \mathrm{y}}\right)$ は

$$
\kappa_{1 \mathrm{y}}=\mathrm{K}_{\mathrm{d}}-\mathrm{P} \times 1 / 2-\mathrm{d} / 2
$$

とした.

上下の頂点の糸中心基準点の $\mathrm{X}$ 座標 $\left(\kappa_{4 \mathrm{x}}, \kappa_{1 \mathrm{x}}\right)$ は,

$$
\kappa_{4 \mathrm{y}}=\mathrm{K}_{\mathrm{ux}}, \quad \kappa_{1 \mathrm{x}}=\mathrm{K}_{\mathrm{dx}}-\mathrm{J} / 2
$$

である。

編地の厚さ方向の $\mathrm{Z}$ 座標については, 糸の直径 $\mathrm{d}=1.25$ $\mathrm{mm}$ により, 上下頂点の糸中心基準点を Z 方向に移動し厚さ を変化させた，Fig. 4 に示すように，糸の直径 d 分だけ移動 する（厚さは $\mathrm{d} \times 2 ）$ と糸は曲線を描いているため隙間がで きる。サンプル編地の厚さの実測值が $2.3 \mathrm{~mm}(\mathrm{~d} \times 1.8)$ で あることから，その隙間は $\mathrm{d} \times 0.2$ となり糸の中心座標は $\mathrm{d} \times$ 0.8 移動する。糸の交錯点の Z 座標 $\left(\kappa_{2}, \kappa_{3}, \kappa_{5}, \kappa_{6}\right)$ を 0 と すると, 上下の頂点の $\mathrm{Z}$ 座標は,

$$
\kappa_{1 \mathrm{z}}=-\mathrm{d} \times 0.8, \quad \kappa_{4 \mathrm{z}}=-\mathrm{d} \times 0.8
$$

となる。

平編地のサンプルの実測值のループ長 $(20.7 \mathrm{~mm}), 3$ 次元 モデルの描画のループ長はともに $\ell=16.7 \mathrm{~d}$ と近似する值と なるため，上記の方式が妥当であると考える。

\section{5. 変化組織のモデリング}

各変化組織のループの組織基準点と糸中心基準点を以下に 示すように求めた。共通式番手に換算して 2 番手の綿麻の手 芸糸により各変化組織のサンプル編地を作成した。ウェール 密度, コース密度, 編地の厚さ, 糸の交錯点の位置の実測と 各変化組織のループと基本ループの比較を行い, 変化組織の モデリングについて検討した.

\section{1 ウェルト（ミス）組織のモデリング}

ウェルト（ミス）の組織では途中で糸が交錯しない。その 
ため糸の方向が変わる基準点が必要ないので糸中心基準点は 開始点となる下のループの頂点 1 点 $\left(\kappa_{1}\right)$ のみとした（Fig. 5)。ただし距離の離れた糸の糸中心基準点 2 点を結ぶ曲線は Z方向にふくらむ構造となり，実際の編目の形状に近似する ことが確認できた（Fig. 6).

\section{2 タック組織のモデリング}

タック組織の編目は下のループの糸と交錯しないため, 下 のループの頂点が上方に引き上げられる構造となっている. そこで下のコースのループと交錯するはずの糸中心基準点 2 点を除去し，4 点の糸中心基準点を通る曲線とした（Fig. 7). タック組織の編目の下の左右のループ頂点の Y 座標 $\left(\kappa_{1 \mathrm{y}}\right)$ は下のループに引つ張られないので上方に移動する。サンプ ル生地の実測值よりタック組織の下のループ頂点の Y 座標 は下の組織基準点の $\mathrm{Y}$ 座標（ $\left.\mathrm{K}_{\mathrm{d} y}\right)$ となる.

$$
\kappa_{\mathrm{ly}}=\mathrm{K}_{\mathrm{dy}}
$$

タック組織の下のループ頂点の X 座標はループの両端で あるので,

$$
\kappa_{1 \mathrm{x}}=\mathrm{K}_{\mathrm{dx}}-\mathrm{J} / 2
$$

またタック組織の次の（隣の）ループの下の頂点 $\left(\kappa_{1 \mathrm{x}}{ }^{\prime}\right)$ も

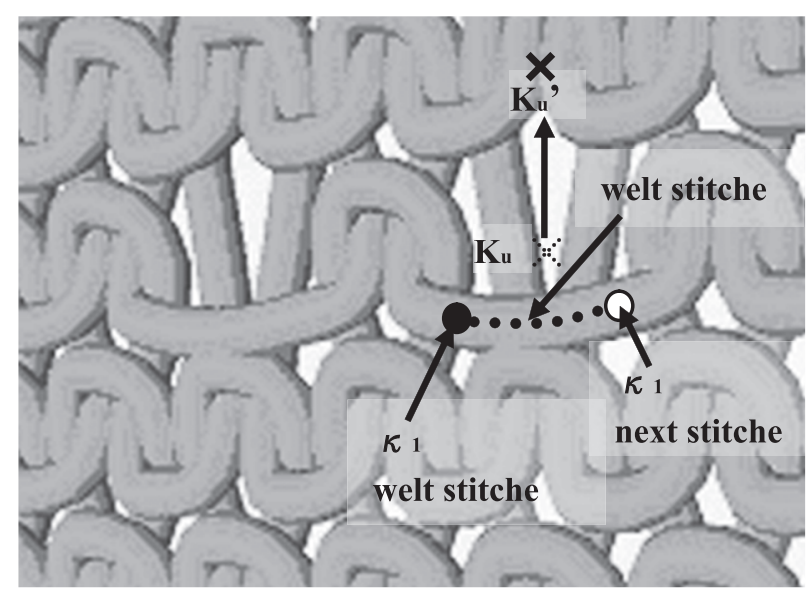

Fig. 5 3D model of Welt-stitches (Miss stitches).

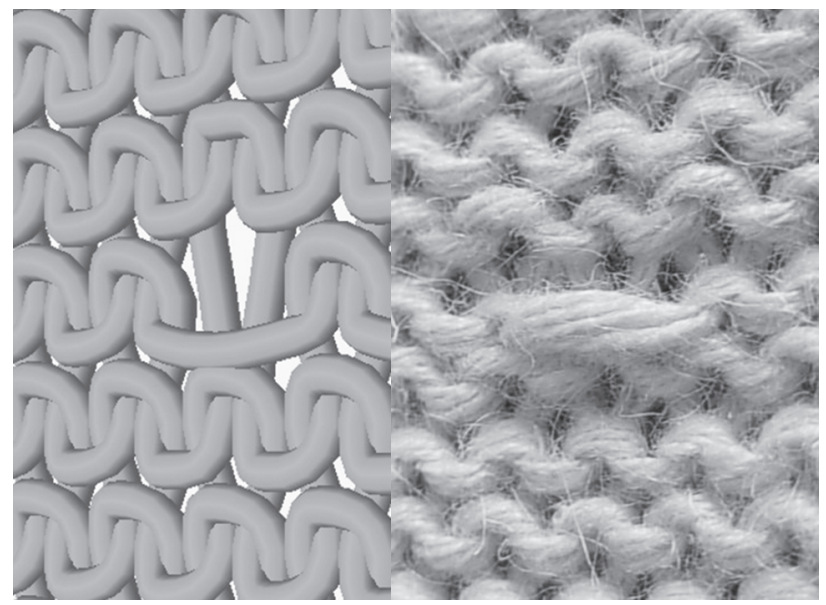

(a) Model

(b) Sample

Fig. 6 3D model of Welt-stitches and sample Knitted Fabric.
引き上げられるため,

$$
\kappa_{1 \mathrm{x}}{ }^{\prime}=\mathrm{K}_{\mathrm{dx}}+\mathrm{J} / 2
$$

となる

上の糸交錯点ではタック組織のループとタック組織の下の ループの 2 本の糸が通るため, タック組織のループの糸中心 基準点 $\left(\kappa_{2}, \kappa_{4}\right)$ を Z 方向へ移動し厚みを出す必要がある. タック組織のサンプル編地の厚さの実測值が $3 \mathrm{~mm}$ であるこ とから，上のループの糸の中心座標とタック組織のループの 糸の中心座標の間隔は $3-\mathrm{d} \fallingdotseq 1.8$ となり, 糸の中心座標は $1.8 \mathrm{~mm}(\mathrm{~d} \times 1.44)$ 移動する.

$$
\begin{aligned}
& \kappa_{2 \mathrm{z}}=-\mathrm{d} \times 1.44 \\
& \kappa_{4 \mathrm{z}}=-\mathrm{d} \times 1.44
\end{aligned}
$$

タック組織の代表的な鹿の子編みで，3 次元モデルはサン プルの編目の形状に近似することが確認できた（Fig. 8).

\section{3 タック組織およびウェルト（ミス）組織の下 のループのモデリング}

タックおよびウェルト（ミス）の組織の下のループはタッ クおよびミスのループと交錯しないため, タックおよびミス

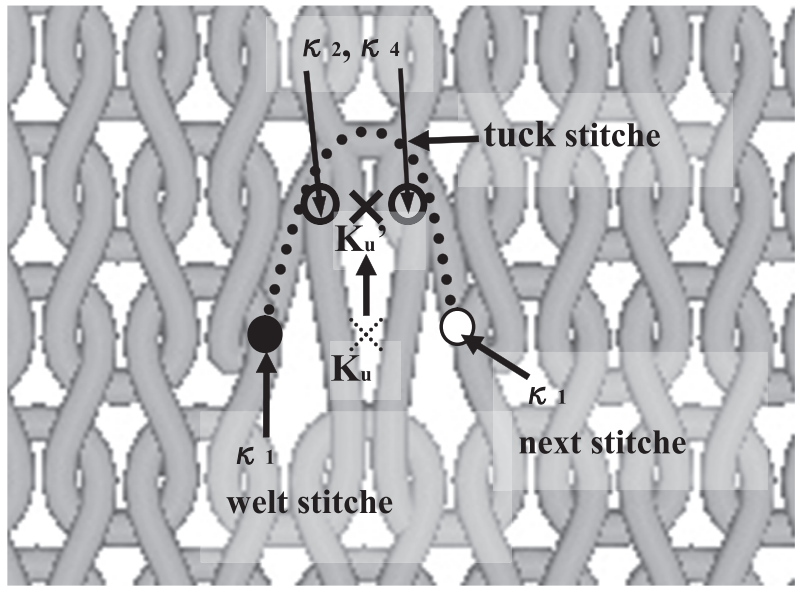

Fig. 7 3D model of Tuck stitches.

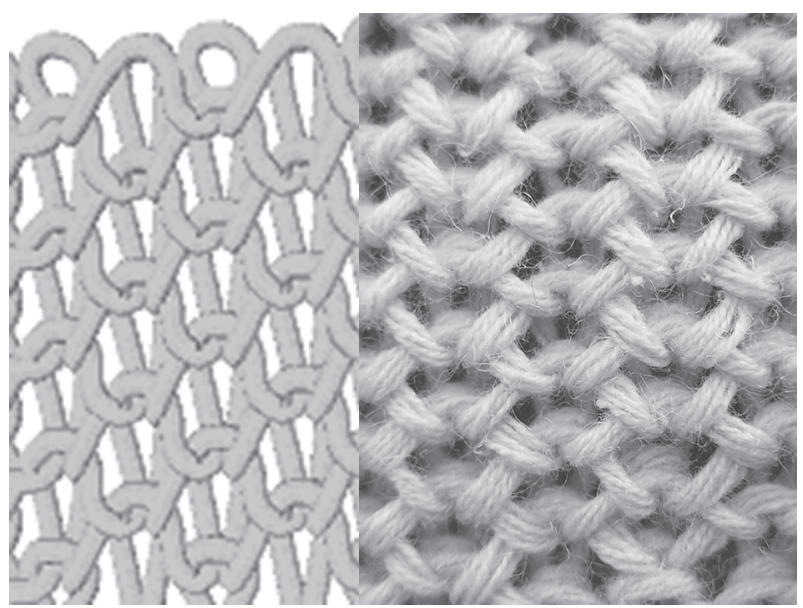

(a) Model

(b) Sample

Fig. 8 3D model of Moss-stitches (Tuck stitches) and sample Knitted Fabric. 
の組織の上のループと交錯する構造となる。よってタックお よびミスの組織の下のループの上の組織基準点 $\left(\mathrm{K}_{\mathrm{u}}\right)$ はさ らに一つ上の組織基準点 $\left(\mathrm{K}_{\mathrm{u}}{ }^{\prime}\right)$ へ移動して求める。 その際 ループ長が変わらないまま糸が引つ張られるためループの幅 が狭くなる. タックの下のループの幅の実測值が $4.2 \mathrm{~mm}$ で あることから, 基本ループの幅の実測值の $5 \mathrm{~mm}$ より左右で $0.8 \mathrm{~mm}$ 内側に寄せるので, 糸の中心座標は基本ループの $\kappa_{3 \mathrm{x}}=\mathrm{J} \times 3 / 8(1.875 \mathrm{~mm})$ より $\mathrm{J} \times 0.08(0.4 \mathrm{~mm})$ 内側に移動 する (Fig. 5, Fig. 7).

$$
\begin{aligned}
& \kappa_{3 \mathrm{x}}=\mathrm{K}_{\mathrm{ux}}{ }^{\prime}+\mathrm{J} \times 0.295 \\
& \kappa_{5 \mathrm{x}}=\mathrm{K}_{\mathrm{ux}},-\mathrm{J} \times 0.295
\end{aligned}
$$

タック組織の下のループの $\mathrm{Z}$ 座標は基本ループのままと した $(-\mathrm{d} \times 0.8)$.

\section{4 移し目組織のモデリング}

移し目組織は上の組織基準点 $\left(\mathrm{K}_{\mathrm{u}}\right)$ を移したい方向の一 つとなりの組織基準点 $\left(\mathrm{K}_{\mathrm{u}}{ }^{\circ}\right)$ に移動し, 上 3 点の糸中心基 準点を求めた (Fig. 9).

上の糸交錯点では移し目組織のループと移し目組織の隣の ループの 2 本の糸が通るため, サンプルの実測值を基に移し 目組織のループの糸中心基準点 $\left(\kappa_{3}, \kappa_{5}\right)$ をZ方向へ移動し 厚みを出した。移し目組織のサンプル編地の厚さの実測值が $2.55 \mathrm{~mm}$ であることから, 上のループの糸の中心座標と移し 目組織のループの糸の中心座標の間隔は $2.55-\mathrm{d}=1.3$ とな り，糸の中心座標は $1.3 \mathrm{~mm}(\mathrm{~d} \times 1.04)$ 移動する.

$$
\begin{aligned}
& \kappa_{3 \mathrm{z}}=-\mathrm{d} \times 1.04 \\
& \kappa_{5 \mathrm{z}}=-\mathrm{d} \times 1.04
\end{aligned}
$$

移し目組織のループの上のループは, 下の移し目組織の ループと交錯しないため, タック組織のループと同様に 4 点 の糸中心基準点を通る曲線となる。 よって糸中心基準点の $\mathrm{X}$ 座標，Y座標は夕ック組織と同じ式で求められる。糸の交錯 点で 1 本ずつの交錯となるため, $\mathrm{Z}$ 座標は基本ループのまま とした $(-\mathrm{d} \times 0.8)$.

移し目組織を用いたメッシュ編みで，3 次元モデルはサン プルの編目の形状に近似することが確認できた（Fig. 10）.

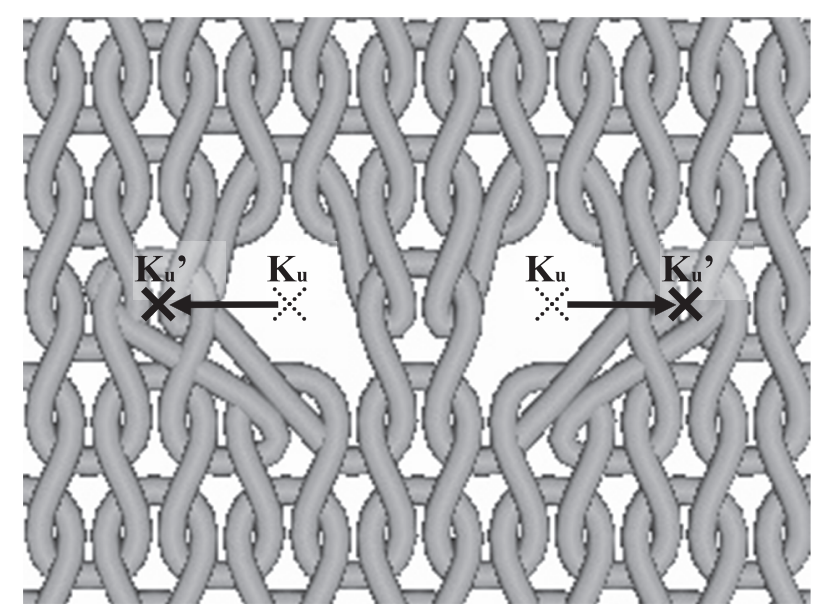

Fig. 9 3D model of Cross stitches.

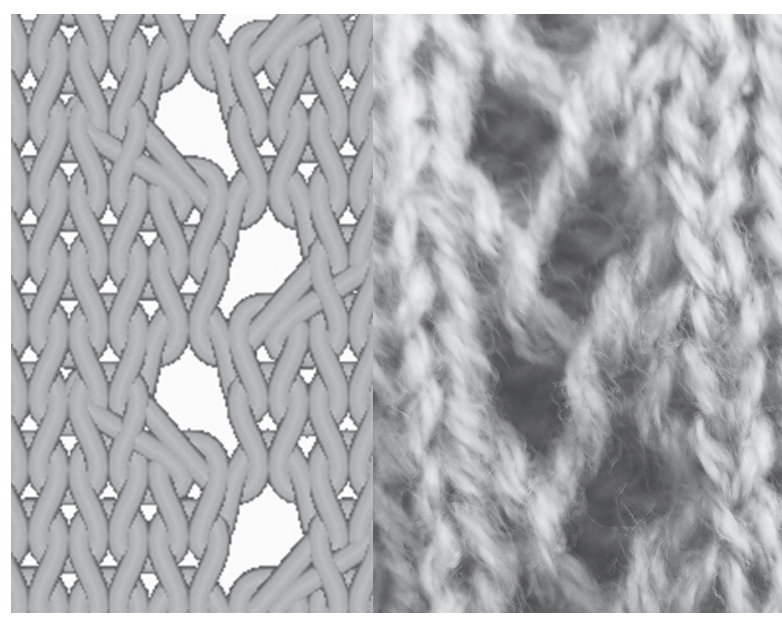
(a) Model
(b) Sample

Fig. 10 3D model of Mesh-stitches (Cross stitches) and sample Knitted Fabric.

\section{5 ゴム編組織のモデリング}

基本の平編と同じ編目構造でも左右の編目の裏表が反転す る組織では, 編地は幅方向で収縮し, 厚さ方向は厚くなる (Fig. 11).ゴム編組織のループは編目がウェール方向で表裏 反転し、コース方向にその反転した組織が並んでいる， $1 \times 1$ のゴム編組織の反転した部分でループが半分 $(\mathrm{d} \times 0.5)$ 重な ると, 表裏のループが完全に重なるため, ウェール密度は 2 倍となる. $1 \times 1$ ゴム編のサンプル編地のウェール密度の実 測值は 3.6 目 $/ \mathrm{cm}$ であり，基本ループのウェール密度 2 目 $/ \mathrm{cm}$ に対して 1.8 倍となる。 そこで組織基準点は，X 軸方向へ $\mathrm{d}$ $\times 0.45$ 縮む方向に移動する.

$$
\begin{aligned}
& \mathrm{K}_{\mathrm{ux}}=\mathrm{K}_{\mathrm{ux}}-\mathrm{J} \times 0.45 \\
& \mathrm{~K}_{\mathrm{dx}}=\mathrm{K}_{\mathrm{dx}}-\mathrm{J} \times 0.45
\end{aligned}
$$

裏表が反転する組織部分では表編ループと亭編ループが重 なり $(\mathrm{J} \times 0.45)$, ループは反対方向へ膨らむため, 裏編のルー プを Z 軸方向に反転するよう交錯点 4 点の系中心基準点 $\left(\kappa_{2}, \kappa_{3}, \kappa_{5}, \kappa_{6}\right)$ を $\mathrm{Z}$ 方向へ移動する. 基本ループの $\mathrm{Z}$ 方向

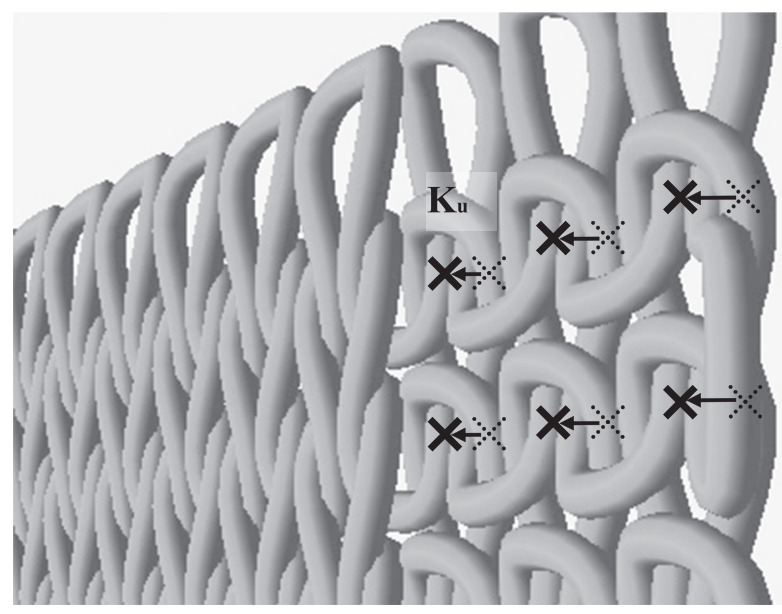

Fig. 11 3D model of Rib-stitches. 
への移動 $-\mathrm{d} \times 0.8$ からさらに $-\mathrm{d} \times 0.8$ 分移動する.

$$
\begin{aligned}
& \kappa_{2 \mathrm{z}}=-\mathrm{d} \times 0.8 \times 2 \\
& \kappa_{3 \mathrm{z}}=-\mathrm{d} \times 0.8 \times 2 \\
& \kappa_{5 \mathrm{z}}=-\mathrm{d} \times 0.8 \times 2 \\
& \kappa_{6 \mathrm{z}}=-\mathrm{d} \times 0.8 \times 2
\end{aligned}
$$

算出されたゴム編組織の編地の厚さ $3.25 \mathrm{~mm}$ とサンプルの ゴム編組織の編地の厚さの実測值 $3.3 \mathrm{~mm}$ が近似すると確認 できた。

$2 \times 2$ ゴム編組織で, 3 次元モデルはサンプルの編目の形状 に近似することが確認できた（Fig. 12）.

\section{6 パール編組織のモデリング}

基本の平編と同じ編目構造でも上下の編目の表裏が反転す る組織では, 上下のループの頂点が編地の表裏反対方向に向 いておりループ長は変わらないため, 厚さ方向は厚くなり, 編地は長さ方向で収縮する（Fig. 13）。パール編組織のルー プは編目がコース方向（Y 軸方向）で表裏反転し，ウェール 方向にその反転した組織が並んでいる。サンプルの実測值を 基に組織基準点 $\left(\mathrm{K}_{\mathrm{u}}\right)$ をコース方向（Y 軸方向）に移動し, 編地の高さ方向を収縮させた。

パール編組織のサンプル編地のコース密度の実測值は 4.2 目 $/ \mathrm{cm}(\mathrm{P} \doteqdot 2.38 \mathrm{~mm})$ であり，基本ループのコース密度 2.3 目 $/ \mathrm{cm}(\mathrm{P} \doteqdot 4.35 \mathrm{~mm})$ に対して約 1.8 倍となる。 そこで組織 基準点は $\mathrm{Y}$ 軸方向へ $\mathrm{P} \times 0.45$ 縮む方向に移動する。

$$
\mathrm{K}_{\mathrm{uy}}=\mathrm{K}_{\mathrm{uy}}-\mathrm{P} \times 0.45
$$

裏表が反転する組織部分ではループの上下の頂点は反対方 向へ膨らむため $(\mathrm{P} \times 0.45)$ ，ループの上下の頂点が $\mathrm{Z}$ 軸方向 に反転するよう董編組織と交錯するほうの頂点の糸中心基準 点 $\left(\kappa_{1}\right.$ or $\left.\kappa_{4}\right)$ を Z 方向へ移動する. 基本ループの Z 方向へ の移動 $-\mathrm{d} \times 0.8$ からさらに $-\mathrm{d} \times 0.8$ 分移動する。

$$
\kappa_{1 \mathrm{z}}=-\mathrm{d} \times 0.8 \times 2 \text { or } \kappa_{4 \mathrm{z}}=-\mathrm{d} \times 0.8 \times 2
$$

算出されたパール編組織の編地の厚さ $3.25 \mathrm{~mm}$ とサンプル のパール編組織の編地の厚さの実測值 $3.2 \mathrm{~mm}$ が近似すると

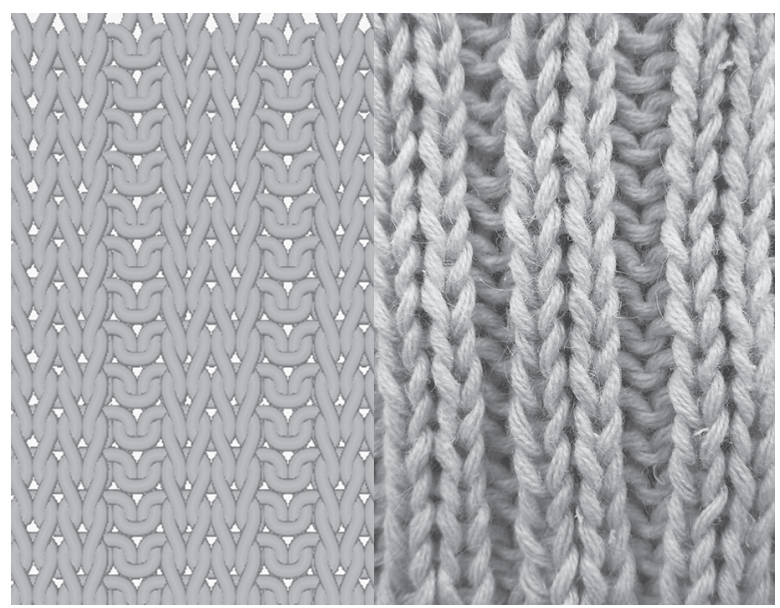
(a) Model
(b) Sample

Fig. 12 3D model of $2 \times 2$ Rib-stitches and sample Knitted Fabric.

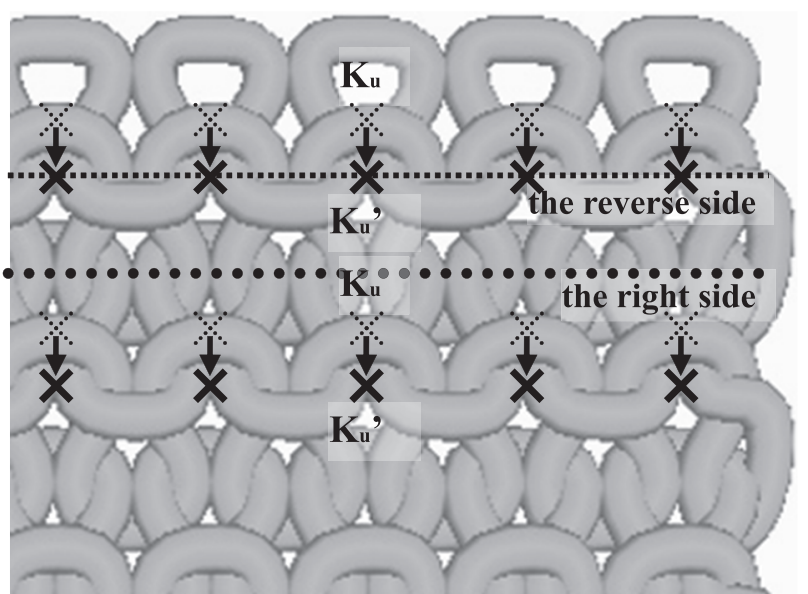

Fig. 13 3D model of Purl-stitches.

確認できた

パール編組織で， 3 次元モデルはサンプルの編目の形状に 近似することが確認できた（Fig. 14）.

\section{6. 結 言}

本研究ではサンプルニット生地の構造解析とニットの幾何 学の理論をもとに, タック, ウェルト, 移し目, ゴム編, パー ル編について 3 次元モデリングするアルゴリズムを構築し た。沉用的なパソコンで使用可能なソフトウェアとなるよう に, 計算量を減ずる手法として組織基準点, 糸中心基準点を 設定した，編み始めから編み終わりの糸中心基準点をカー デイナルスプライン曲線で描画することでなめらかなニット の曲線モデルを描いた。構築したアルゴリズムをもとにタッ ク，ウェルト，移し目，ゴム編，パール編の組織を含む編地 を, 組織図, 番手, 密度など基本設定の入力を行うことで, 対応した編地の 3 次元モデルを表示する「よこ編組織の 3 次 元モデリングソフトウェア」の開発を行った.

本研究の成果により，よこ編の三原組織（平編，パール編， ゴム編）に加えタック，ウェルト，移し目の3 次元モデリン

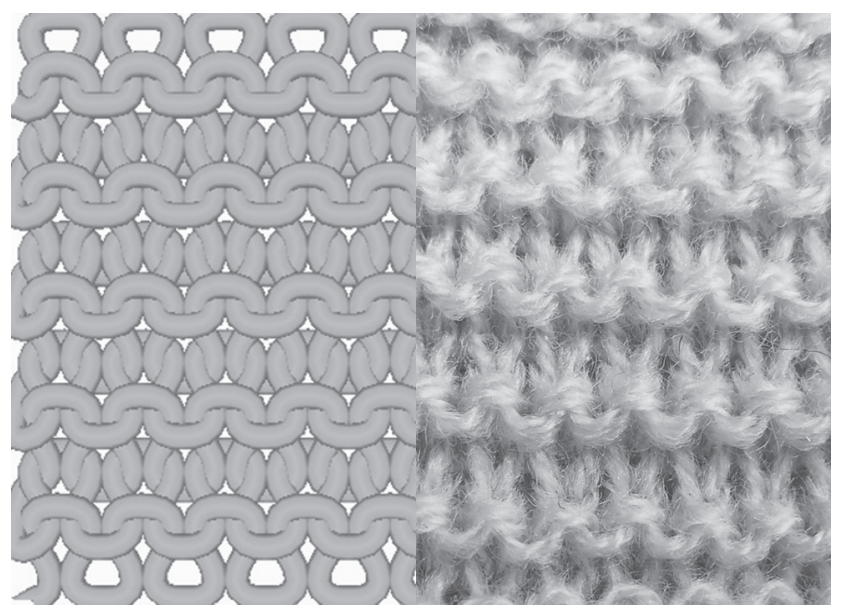

(a) Model

(b) Sample

Fig. 14 3D model of Purl-stitches and sample Knitted Fabric. 
グを汎用的なパソコンで確認できるため, 編地の編成知識を 持たない者の編地の知識の習得, ニット生地を製品に使用す る場合の編地の構造の確認に使用できる。編地は伸縮性に富 むため, 衣服の場合大まかなサイズでも着用者のサイズに合 うが, ウェール密度, コース密度から編地を計算值として求 め出来上がりのサイズをシミュレーションすることでより体 形に合わせた製品，また衣服以外の用途で詳細な設計が可能 な製品の開発を可能にすることが考えられる.

本研究の一部は日本繊維機械学会第 62 回年次大会で発表 した。

\section{References}

[1] F. T. Peirce (1947) Text Res J, 17, 123-148
[2] Leaf, Glaskin (1955) J. Text. Inst., 46, T587

[3] Tabata M (1967) "kisosen-ikougaku [III] dai 2 hen amimono", pp 151-184, nihon sen-ikikaigakkai

[4] A Kurbak', O Ekmen (2008) Text Res J, 78, 198-208

[5] A Kurbak', O Kayacan (2008) Text Res J, 78, 279-288

[6] A Kurbak', A S Soydan (2008) Text Res J, 78, 377-381

[7] O Kayacan, A Kurbak' (2008) Text Res J, 78, 659-663

[8] A Kurbak', O Kayacan (2008) Text Res J, 78, 577-582

[9] Saijo K et. al. (2009) Proceedings of the 62nd Annual Conference of TMSJ, 36-37

[10] Suzuki N, Japan Patent, JP 2005-120501

[11] Morimoto S , Japan Patent JP 2009-145959

[12] Furukawa T, Japan Patent, JP 2007-293636 